\title{
13. Positioning order, disorder and creativity in research choices on local development
}

\author{
Silvia Sacchetti and Roger Sugden
}

'fatti non foste a viver come bruti ma per seguir virtute e canoscenza'

[You were not made to live as brutes but to pursue virtue and knowledge]

Dante Alighieri, 'Inferno', Divine Comedy, Canto XXVI

\section{PLACES IN AN ORDERED AND HIERARCHICAL SYSTEMS}

What the contributions in this volume have tackled is the possibility for an institutional dynamism that impacts not only on the characteristics of 'localities' and their position in a hierarchical and ordered system of relationships, but on the nature of the system itself. Is hierarchy a necessary and desirable condition for the development of economies? This is a perspective that, in line with Veblen and Hodgson's interpretation, addresses phylogenetic change (Veblen, 1898; Hodgson, 1993).

The idea of hierarchy may be positioned in some philosophical perspectives and views of the world which have associated the notion of hierarchy with that of place. In the Divine Comedy, written in the 14th century, the author, Dante Alighieri, undertakes a symbolic journey in the afterlife. His course, as defined by the Christian tradition, is articulated through the places and the gatherings which delineate an imaginative space, whose structure reflects the Greek and the Jewish-Christian cosmology (Stabile, 2007). For the latter, heavens are structured in different layers, each one of which - the empyrean or the place of peace where the chosen sit; the stars and the planets; the living beings, who are born and perish within the terraqueous globe - is subject to the natural law of circular and uniform motion or, in other words, each layer is bound to perfection. In 14th century Italy, when Dante writes - localisms and egoisms amongst and within cities were associated with precariousness, disorder and uncertainty. It was a time of conflicts during which hierarchy was advocated as 
the ordering and unifying principle, not only at the level of politics, but also for linguistic reasons (ibid.).

The neo-Platonic hierarchy of heavens, as Stabile (2007) suggests, defines space by means of subsequent specifications, moving from an indistinct totality to a multiplicity of elements, each with its own characteristics. The notion of place substitutes that of indistinct space. Each place is situated, that is, it is defined by what surrounds it, by the position it occupies in the world hierarchy. Because of the concentric structure which results from this notion, places find their own identity within an ordered and hierarchical system, so that each place's coordinates are defined indeed by other places (ibid.). In the last resort, each place - whether sited at a lower or upper layer - contributes to define at least another place, thus conferring significance to the system. ${ }^{1}$

\section{ECONOMICS, ORDER AND HIERARCHY}

Economics probably epitomises the idea of an ordered system in which change is normally contemplated and explained by identifying dynamic elements within pre-defined paths of development. If we consider the idea of a tendency towards 'normality', which was criticised by Veblen ([1898] 1998) and which the neo-platonic perspective on space emphasises, we can perhaps appreciate even more why in so doing economics 'can not be an evolutionary science' (ibid.). Rather, it tends towards an exogenous 'topographic order', within which each element (e.g. resources, regions, but also values and preferences) has its own place. Such an order obeys a hierarchical principle at the micro, for instance the exogenous preferences assumption, as well as at the macro level, for instance in the debated and still influential theory of development stages (Rostow, 1959), for which localities follow an obliged path towards 'normality' sketched, for example, in sectoral terms, or with respect to wealth, as well as through comparative analogies with the competitiveness of other places. This perspective delineates a static and marked lane towards predefined objectives, assuming an order of preferences at the macro level as well.

More generally, Veblen's critique to the idea of equilibrium as the law defining a tendency to 'normality' can be traced back to the neo-platonic ordering principle. Consistently, resources return to the place that an efficiency-maximising system confers to them. As argued by the Austrian school, the market and the price mechanism would serve this purpose (Hayek, 1945). However, as transaction cost theory has suggested, price signals might not be sufficient to disentangle the complexity attached to economic decisions. The knowledge required for choosing amongst 
alternatives and the associated costs would require different forms of economic governance, according to the classic argument that opposes markets and hierarchies. In that context, hierarchy serves the purpose of creating certainties in a system that would otherwise be characterised by a great deal of uncertainty.

Within the usual hierarchical organisation, such as the large corporation described by Chandler (1977), authors have read the introduction of the managerial function as a means for 'buffering' the environmental uncertainty and complexity of expanding markets (Langlois, 2003). This, it is argued, was needed to create a more stable context in which investment commitments to capital-intensive sectors could be implemented, and production could be run at its minimum efficient scale. That analysis is consistent with Knight (1921). He contended that, without uncertainty, management would be concerned with the coordination of activities in a routine sort of manner and without responsibility.

However for Knight (1921, p. 268; quoted in Coase, 1937, p. 400; emphasis added):

\begin{abstract}
With the introduction of uncertainty - the fact of ignorance and the necessity of acting upon opinion rather than knowledge - into this Eden-like situation, its character is completely changed.... With uncertainty absent man's energies are devoted altogether to do things; . . . in a world so built that perfect knowledge was theoretically possible, it seems likely that all organic re-adjustments would become mechanical, all organisms automata. With uncertainty present, doing things, the actual execution of activity, becomes in a real sense a secondary part of life; the primary problem or function is deciding what to do and how to do it.
\end{abstract}

As a consequence of uncertainty, Knight perceives it as 'imperative' to have direction (or, in his words, 'cephalization') as a form of governance - a point that Coase (1937) addresses and criticises by arguing for the role of the price mechanism under particular circumstances.

The for-profit firm, the prevailing economic organisation of capitalist systems, is a typical hierarchical structure. Its governance does not have democratic roots (Borzaga and Tortia, 2009) or, to put it differently, does not originate from a delegation process. As a matter of fact, whilst with democracy we say that the people are sovereign (although it is through a delegation process that representatives get the power to take decisions collectively), in the for-profit firm the command and decision-making power belongs to those who retain property rights and alternatively to the management or, more generally, to a restricted group of people (Cowling and Sugden 1998). In that case, we cannot talk about a delegation process which springs out of the stakeholders' will (workers, for instance, or the local community as a whole) and which is based on a democratic rule (compare 
delegation with the contractarian perspective put forward by Sacconi and Degli Antoni). The founding institution for such a firm is property rights which allow for strategic control over production decisions. Consistently, by means of a labour contract, the employee hollows out to the employer the power to decide over the use of his/her time in exchange for a salary (cf. Screpanti 2001). Moreover, beyond property rights, the firm can eventually exert its control by means of market power over consumers, suppliers and subcontractors (Cowling and Sugden, 1998).

There is, for these reasons, a substantial difference compared to, for instance, democratic systems. Under current forms of democracy, the governed - in principle - are also those who govern, by delegation. Consistently, state institutions - with that system of counterweights amongst powers initially advocated by Montesquieu ([1748] 1989) should be functional to an ordering principle that serves the public (or publics, according to Dewey, 1927). That is to say, to recall a Smithian argument, that institutions should serve the purpose of safeguarding the positive and negative freedom (Berlin, 1969) of all actors, in particular those with the weakest (economic) power.

To state it differently, institutions may also be seen as instrumental to the need of not falling back to that Hobbesian state of nature where man is wolf for other men. ${ }^{2}$ We are in front of a very different idea from that of 'free market competition' (across individuals and, at a meso level, across firms) taken as the ordering principle of economies. That notion of competition put forward by Alchian (1950) as well as by Hayek (1982) has heavily shaped the understanding of economic development in terms of the 'survival of the fittest'. ${ }^{3}$ As Hodgson (1993) has noticed, the fittest organisations have been identified with the prevailing organisational structure of contemporary economies, the for-profit firm. However even the simple fact of representing the majority of firms, does not mean that they are the most efficient, or the better suited organisational structures for societies. Furthermore, the liberalist approach to economics focused on maximisation has, paradoxically, eliminated free will (ibid.). In fact, once we introduce uncertainty, orthodox rational choice stops being founded on the purposeful reasoning in individuals, whilst explaining action in terms of mere "programmed responses to the circumstances in which those agents are placed' (Loasby, 1991, p. 1, quoted in Hodgson 1993, p. 218).

Following Knight (1921), under uncertainty production requires exclusive decisional structures (the managerial function) which introduce power asymmetries within but also amongst organisations. But because of the relative indeterminateness associated with intentionality of action (as against the maximisation assumption on rational agents) and of the imbalances created by uncertainty, the market - although assimilated by many 
to the idea of freedom - without rules would probably be a good approximation of the state of nature and precariousness, of the uncertainty and disorder that the neo-platonic philosophy wants to avoid with its idea of cosmology.

\section{THE HUMAN PERCORSO TOWARDS SELF- AND DE-LIBERATION}

Under uncertainty, whether the governance mechanism is exclusive or participatory, we do not find such a thing as complete information (Coase, 1937; Williamson, 1985) and knowledge (Hodgson, 2005), where the notion of knowledge is dynamic and related to the differentials in learning and forgetting of human beings, organisations and society. To get round these limitations, it has been argued that institutions play the role of a collective mind by 'remembering' in the place of individuals, organisations and society (Douglas, 1987), and by simplifying individuals' tasks (Hayek, 1967; Egidi 1987). ${ }^{4}$ That happens as habits and routines ${ }^{5}$ indirectly replicate themselves by eventually activating specific behaviours. ${ }^{6}$

From the limited nature of human knowledge follows its perfectibility. We can, in other words, expect knowledge to evolve and impact on humans' understanding of their own desires, preferences and choices both as individuals and as publics. Institutions, such as habits and routines, indeed provide an ordering principle as they can be conceived as shared dispositions or propensities (Dewey, 1922) on which individuals and organisations can activate higher deliberation processes (Hodgson, 2003).

It is institutions, for example, which can be thought as defining the space of production and exchange and make it work towards an order. Such an order, we suggest, would be in turn a means for achieving socially desired and democratically identified objectives, rather than an end in itself, the argument being that this specific conceptualisation of order allows uncertainty to be present. From this perspective, the rules that through democracy are shaped by publics should - in principle - avoid social and economic exclusion. Deliberative processes, by involving rather than excluding, would allow for differences to emerge across actors and places, thus encouraging and offering a more favourable context to the flourishing of variety. ${ }^{7}$ This is not a straightforward process, as it requires the creation and use of deliberation procedures for mutual learning and consensus formation, including horizontal communication amongst a plurality of publics, as noticed by Sugden, Te Velde and Wilson (Chapter 10).

At its heart, we could say that deliberation constantly applies the principle of the Civitas. ${ }^{8}$ Systematically, according to what has been argued in 
Chapter 9, deliberation becomes the attitude reflecting the need to include those publics which are, at different times, interested in specific decisions. With respect to the neo-platonic and Dante's-like order, there is a change in the coordination mechanism. Under a prospect of inclusion, governance mechanisms do not reflect hierarchical principles through, for example, the government of a 'sovereign' - who might be enlightened but certainly not omniscient and not even the repository of justice alone, as Young (2002) noticed. Rather, we suggest that coordination occurs by means of the democratic and ordered deliberation amongst publics (Sacchetti and Sugden, 2008). The objective is to get to a shared decision by means of a deliberative discussion and communication, rather than through a decision imposed from the top of a hierarchy to which a contractual resolution has conferred the right to decide for others.

Deliberation, therefore, is conceived here as an ordering principle (ibid.) which, differently from other procedural criteria, is also inclusive and egalitarian (Young, 2002). On this, in particular, Adaman and Devine (2001) have argued that deliberation allows for an evolutionary process of collective learning. Hodgson (2005), in contrast, argues that innate cognitive limitations can restrict the scope for deliberative decision-making. Stemming from a recognition of the limitations intrinsic in the nature of human rationality as well as in knowledge and learning both as individual and collective processes (Rizzello, 1997; Bruni and Sugden, 2007), we suggest that, in order to understand its limits and potentials, an analysis of deliberation needs to recapture the institutional focus of Veblenian origin on habits, as well as the individual dimension of interpretation and choice.

What accomplishes deliberation before, during and after the communication and decisional process points towards the individual's cognitive or thinking abilities, i.e. to his/her ability to understand a specific phenomenon eventually against existing social habits (Dewey, [1910] 1991). This stage, however, is reached through specific behaviours which are mediated - at a procedural level - by those same deeply rooted social habits, including the impact of specific inner beliefs on behaviours that can lead to effective learning. That paradoxical situation is emphasised by Veblen (1898) but also by Dewey ([1910] 1991), where he reasons that in order to overcome the 'propagation of error' (ibid., p. 21), the mind must be trained (e.g. through education) to the formation of habits that privilege that kind of thought which can 'discriminate between beliefs that rest upon tested evidence' and those that conversely are based on 'mere assertions, guesses, and opinions' (ibid., pp. 27-28).

The link between one's dispositions or habits, their actual understanding and contextualisation, as well as the behaviours that follow is mediated, 
in the last instance, by the individual and his/her own self (Hayek, 1952; Polanyi, 1967). We, therefore, suggest that de-liberation ${ }^{9}$ is an element of humans' curiosity, of the desire for knowledge which ultimately aspires to self-liberation (e.g. from 'false beliefs' as Dewey would say). The latter (which would be a privileged terrain for philosophy and psychology) is, from a complementary perspective, the field over which artistic expression moves and, more generally, where the thinking individual, under particular conditions, chooses and acts.

Motivational aspects and preferences, as stressed in different parts of this volume, are relevant aspects for an understanding of the 'percorso' that each individual chooses to undertake. In that context, to give space to diversity represents a necessary recognition for the differences across individuals and - as Grönblom and Willner notice in Chapter 6, recalling Elster (1986) - for the multiplicity of selves that may coexist at a given point or unfold over time.

As an illustration, Bertolucci (Bachmann and Bertolucci, 1973), describes the act of filming as the creation of a learning relationship between the film-maker and things, spaces and people, in search of one's own self-liberation. ${ }^{10}$ This process, which does not refer to the arts only but which in the arts finds perhaps a privileged context, requires that individuals have the space to think, see, imagine and to let in the unforeseen. Freedom, from this point of view, relates to the possibility to exert one's own original idle curiosity (Veblen, [1898] 1998). Collective processes of de-liberation interact over time with the sphere of self-liberation, without substituting it, as the private sphere and the public sphere of reflection are complementary, although the latter could not exist without the former.

This links consequently to the dynamic element of human research, which may be subject to different degrees of intentionality and intensity. A consideration of 'time' allows talking of a 'percorso'. The film-making experience assumes a specific meaning in that respect:

I still seek the very specific way of representing how time passes - that particular psychological passage of time which gives a film its style. Perhaps it is a matter of 'percorso', of how a man moves through time, in the historical and in the practical, daily sense. (Bachmann and Bertolucci, 1973, pp. 6, 7)

The reason we would rather refer to a 'percorso' in the search of self- and de-liberation (the individual and the publics) is that we want to take distance from the notion of 'evolution' in economics put forward by Alchian (1950) and Hayek (1982). Such approaches are based on the idea promoted by earlier social evolutionists such as Spencer ([1876] 1969), who privileged the notion of human 'survival' and of competition for survival, whilst with a focus on the 'percorso' we want to recapture essentially the 
intellectual and practical experience of human 'life'. It is the 'percorso' partly designed by the choices of human beings towards their liberation, towards understanding, but also affected by existing institutions and by their inertia (Veblen, [1904] 1996), as well as by path dependence on previous events (Arthur, 1989).

There is teleology in what we suggest. What, for instance, the notion of 'mutual dependence' across economic actors entails can be defined as a benchmark, an ideal type objective (Sacchetti and Sugden, 2003). ${ }^{11}$ The objective in itself, although identified, could be unachievable, but that does not make it less desirable. From this perspective we reposition our analysis from 'winners' in the competition for survival towards a focus on the process. ${ }^{12}$ This is why, against current trends, we suggest not to judge only from the achieved, but to focus on the running path, on the choices as well as on tendencies ${ }^{13}$ towards (or, more dramatically, against) a desired objective.

A focus on the 'percorso' pulls us out from the culture of achievement in which we are submerged (Bachmann and Fellini, 1980-81), and recaptures a realistic, ${ }^{14}$ less mythical perspective by putting emphasis on uncertainty, and on the dialectic between order and disorder (see also Christensen, 2007).

\section{DISCOVERING 'LAWS', DESIRES AND PREFERENCES THROUGH EXPERIENCE}

What, then, is the role of rationality in such a context? As Sugden (1991) notices, according to Jevons' transposition of Humean theory, rationality is instrumental, i.e. an instrument to achieve the maximisation of utility (Jevons, [1875] 1905). Such an end is possible if we assume that preferences are complete and transitive and consistent with choices, which are understood in the simplified context of 'the ordinary business of life' or the 'lowest rank of feelings' (ibid., p. 91).

Stemming from the particular debate on which Bruni and Sugden (2007) comment, we argue that instrumentality is not adequate to explain all economic interaction or, more broadly, all social interaction. A first criticism of instrumentality is that, at the conceptual level, by identifying rational action with the maximization of utility, human choice involves only programmed responses to an exogenously given objective, thus removing the purposeful behaviour of actors (Hodgson, 1993). Second, under orthodox rational choice theory, uncertainty disappears from the context in which humans make their judgements and chose (ibid.). Contextually, Alchian (1950), subsequently criticised by Penrose (1952), located maximising 
behaviour in evolutionary reasoning, arguing that only maximisers are bound to survive. Hodgson (1993) effectively notices that, by denying free will, orthodox theory made 'the individual a prisoner, not simply of the social environment, but of his or her immanent and often invariable preference functions and beliefs' (ibid., p. 218).

How, then, is knowledge achieved by individuals? Having emphasised the importance of the 'percorso', we would put forward a notion of rationality based on experience (Dewey, [1910] 1991), including the use of reason, or critical thinking, as a fundamental component both at the individual and at the collective level.

A number of contributions have emphasised that people's mental capacities to learn from experience are subject to limitations and errors (Bruni and Sugden, 2007; Hodgson, 2005). However, experience is here a synthesis of the use of reason and evidence at the level of the self (or multiple selves) and across different individuals at different times. Rather than transcending space and time, conclusions stemming out of this process would be contingent on the individuals and the publics involved in that particular deliberation process at a given time, as the identification of different places, individuals and publics would require further deliberation. ${ }^{15}$

The Deweyan notion of experience, in particular, is a synthesis of the personal and public dimensions in their interaction with the environment:

Experience is the result, the sign, and the reward of that interaction of organism and environment which, when it is carried to the full, is a transformation of interaction into participation and communication. Since sense-organs with their connected motor apparatus are the means of this participation, any and every derogation of them, whether practical or theoretical, is at once effect and cause of a narrowed and dulled life-experience. . . What is distinctive in man makes it possible for him to sink below the level of the beasts. It also makes it possible for him to carry to new and unprecedented heights that unity of sense and impulse, of brain and eye and ear, that is exemplified in animal life, saturating it with the conscious meanings derived from communication and deliberative expression. (Dewey, [1934] 2005, p. 23, emphasis added)

Along the 'percorso', values, but also latent habits as well as objectives and preferences need to be constantly assessed or discovered. In this context, therefore, rational actions are those that lead individuals to continuously scrutinise and update their understanding of actual objectives, preferences ${ }^{16}$ and desires, ${ }^{17}$ consistently with their inner values, which are subject to a process of discovery as well. At the same time, through deliberation individuals relate their evolving laws, desires, objectives and preferences to those of other people and publics.

From that perspective, rational behaviour is therefore a 'meta-behaviour', 
as it leads to an appreciation of the 'percorso' and the dynamics in humans' search of values, habits, desires, objectives and preferences. Action (including imagination and thought) is needed at time ' $\mathrm{T} 1$ ' in order to explore inner wishes, learn and eventually reshape objectives and preferences accordingly at ' $\mathrm{T} 2$ ' before you can act at time ' $\mathrm{T} 3$ ', when further meaning is attached to events and thoughts, feeding them back as new inputs in the process of meaning and learning. Such a process is effected by the opportunities and constraints attached to the environment, to habits as well as to the human mind, but remains fundamentally a 'percorso' towards 'liberation', towards how to improve our understanding of who we are in terms of what we think acceptable principles are, following life experiences. This process builds upon itself and is based on experiencing things both at the level of the self and at the level of other publics. Such 'eagerness for experience, for new and varied contacts, is found where wonder is found' (Dewey, [1910] 1991, p. 31, emphases added).

Action, according to what we suggest here, is not to maximise pleasure or to minimise pain, as hedonistic approaches suggest. Nor it is a direct consequence of our tastes, as Pareto argued, because we might not know them. Rather, action is to improve our knowledge. This is possible only if action becomes 'experience' as the latter includes the thinking functions of the mind (Dewey, [1910] 1991). ${ }^{18}$ The Cartesian 'cogito ergo sum' (I think therefore I am) could be rephrased and extended here in terms of: I experience therefore I am. The Shakespearean question of being, from this particular perspective, could be interpreted as lining up the conditions under which an individual can proceed towards knowing him/herself and chose consistently with his/her perceived values, habits, rules and desires. The point about consistency implies the retrieval of instrumental rationality (or hypothetical imperatives, in Kant's terms), which however cannot exist without the initial 'wonder' or 'idle curiosity' which prompt in people the desire for knowing.

For human beings, knowing themselves and understanding themselves comes before any assumptions about maximisation of pleasure as being the objective or tastes. Knowledge may give pain, indeed. The question is not: how do human beings maximise pleasure, but how can they understand their values, their desires and create the opportunities to coherently discover preferences that are consistent with such (perceived) inner wishes and understanding of things. Critical thinking is essential to this process. It is a way of acting and making sense of action at the same time.

Particularly, we have argued (Chapter 9) that critical thinking can be stimulated by de-liberation and by activities such as the arts or science, which are actions impacting on our understanding and are, therefore, at the basis of a 'percorso' of desires and preferences discovery. We suggest 
that these develop when both the private and the public aspects are considered, that is, if preferences are sought whilst making sense of what is experienced both as a personal reflection as well as interacting with publics.

\section{UNCERTAINTY IN LEARNING AND RESEARCH ACTIVITIES}

In stressing the importance of intellectual curiosity and of the use of reason and evidence along the 'percorso', we would nonetheless highlight the significance of intuition. When discussing sense and sensibility, Docherty (2008) refers to the study of English and, more generally to 'the proper place ... of literature ... within a society'. He considers the deficiencies of having 'a form of knowledge that was not "lived", not actually "felt" at the inner level of sensibility' (ibid., p. 4). The result of such a form might be seen as 'a triumph of the industrialisation of the human spirit', a failure to appropriately balance 'sense or reason and sensibility or feeling' (ibid., pp. 4-5). The idea is that the study of literature might demand a balance, but we would argue that the same could be said for the study of economies.

One hypothesis is that an understanding of a poem, painting, machine or, indeed, economy that is not felt might be in some sense lacking. For example, an engineer or economist might first feel what is failing in a particular machine or economy and then make that feeling tangible, expressing it through reasoned argument and correcting the failure; but such reasoning and correction might not occur without the feeling, other than by chance. Another hypothesis is that sensibility is a determinant of people's capacity to be imaginative; that understanding of economies requires imagination; therefore that an academic studying an economy needs sensibility for the subject in order to unleash his or her full creative potential in exploring what is and might be happening in the economy. Without sensibility, imagination is constrained and understanding limited.

What does that appreciation of sensibility imply for academia? The idea here is that sensibility can guide individuals not only towards the knowledge of values, desires, preferences and objectives from an ethical perspective, but also from a scientific point of view. Our approach - in line, for instance, with what has been argued by Francesco Sacchetti in Chapter 12 - suggests to organise research and learning activities so as to nurture the intrinsic creativity of each participant. Chomsky (1975, p. 164) argues that the purpose of education is not 'to control' a person's 'growth to a specific, predetermined end, because any such end must be established by arbitrary authoritarian means; rather, the purpose of education must be to permit the growing principle of life to take its own individual course, 
and to facilitate this process by sympathy, encouragement, and challenge, and by developing a rich and differentiated context and environment.' Similarly, our concern is to forsake the attempted certainty associated with predetermined outcomes and instead to create discipline-spanning and discipline-fusing spaces that: (1) enable the positive freedom of scholars (faculty and students alike) to identify and pursue a unique academic agenda that both reflects and contributes to the development of each person's intrinsic creativity; (2) provide a sympathetic yet challenging environment that emphasises scholars' creative interaction, together and with other interested publics.

Rather than analysing predefined topics in search of predefined outcomes, the cost of which can be omission of potentially relevant and insightful issues, we suggest that topics and analysis be allowed to emerge by the creation of spaces where uncertainty and some degree of disorder are accepted, across disciplines, across methodologies, across publics, across social spheres, across localities. An objective is to be open to complementarities with others so that we might discover and pursue new and unique opportunities, while maintaining and developing core competencies as academics. This enabling of disorder and uncertainty is in interesting and stark contrast to what Khurana (2007) has argued to be a foundation of US business schools.

\section{CREATIVITY AND UNCERTAINTY IN RESEARCH OVER LOCAL DEVELOPMENT STRATEGIES: A CASE FOR ACTION RESEARCH}

The relationship between universities and territories has been shaped within policy and academic environments around the notion that academic research may benefit from case studies and observations based on regional experiences and, vice versa, that regions and localities may benefit from the insights that academia might give with respect to specific economic problems. This view stems, not least, from the way in which science develops, including, for example, the intrinsic interplay between deduction and induction, between the development of hypothesis and the observation of specific, perceived realities.

However, recent evolutions (think for instance about Porter's major international influence on policies for competitiveness and promotion of global chains (Porter, 2003)) show that economic thinking is heavily drawing on policy objectives and, not least, on the understanding that policy-makers have of the notions underpinning those objectives. One possible shortcoming for academics and economic theory is to lose analytical 
power and critical perspective or, in other words, to preclude the analysis of different ways forward, other than those currently embraced.

In May 2007 we organised a Festival on Creativity and Economic Development which was hosted in Gambettola, a ten-thousand-inhabitant municipality in the Emilia-Romagna Region, in Italy. The initiative came from concerns coming out of our research interests as academics on the one hand and, on the other, it was the result of policy-makers' will and openness to find new ways forward. In particular, the idea was to stimulate and nurture people's own imagination and creativity, so that together they could shape and seize opportunities for critical thinking, for talking and discussing with each other, for respectfully sharing opinions and arguments, thereby increasing the diversity of ideas and perspectives, for finding mutually respectful and beneficial ways forward in social, economic and political activities.

This Festival included seminars and discussions involving leading academics and practitioners; these were sometimes essentially 'academic' and at other times targeted at wider publics. The seminars were all linked to a series of performances and exhibitions - sculpture, photography, dance, poetry, theatre, music, film - that explicitly focused on the relation between creativity and economic development. The presenters, performers and exhibitors came from various countries, and overall the one week event attracted some 3000 visitors.

At the outset, as academics, we had severe doubts that it was possible to encompass, in one event, academic analysis and artistic performances, whilst also actively engaging people from the local community. In this regard, however, the Festival combined the contributions of theatre actors, architects, citizens, economists, entrepreneurs, graphic artists, poets, policy-makers, political scientists, students.

To explore old and new issues in economic development in different ways meant to create new spaces as well as, borrowing some of the evolutionary terminology, 'new combinations'. Against the current approach to research, which relies on predefined issues and outcomes in order to increase certainty, the intention was to let the topics emerge by creating space across localities, across disciplines, across social spheres. Although increasing the uncertainty of outcomes, the new space and combinations would eventually dynamically change our routines as academics. And because routines involve a strong tacit dimension, they may not be easy to imitate (Dosi, 1994, p. 233), thus eventually opening up to new topics or to a different experience of interaction. Moreover, new routines have the potential for tooling up a university or a locality with distinctive capabilities, therefore providing a basis for differential performance.

The dangers associated with what we could call a holistic approach are 
that the creation of new spaces requires the acceptance of some specific risks, at least in the first stages of development. In particular, a major difficulty could come from habits of thought and routines, as academics might keep on sticking to what they know best. As the research environment changes, cognitive structures could fail to adapt quickly enough to recognise relevant objects and relationships. However, borrowing from industrial analysis, new opportunities can be developed, where "such opportunities are partly a lagged function of "fomentation" "diversity" and "search activities" (Dosi, ibid., p. 234)'. In this respect, academics might need to elaborate new routines, but they do not change their core competences as academics. Rather, they develop complementary assets which are crucial for discovering new opportunities.

A key feature of the Festival is that it was consciously designed to foster unforeseen outcomes, all being consistent with participants mutually respecting each others' experiences, skills, perspectives and aims. In seeking this, we deliberately introduced and sought a critical perspective on accepted approaches. In fact, we would argue that in practice the Festival did indeed yield unforeseen outcomes, in terms of analysis, understanding, and cooperation. ${ }^{19}$ Moreover, it contributed to activate latent attitudes towards participatory governance by activating some radical changes in the local institutional structures governing the complex and dynamic set of publics related to the specific activities that characterise the town.

Experience with the Festival is also instructive on the issue of engagement with interested publics whilst retaining independence from those publics. In organising the event we had strong support from the Mayor of Gambettola on the basis that he and we would play explicitly different roles. Specifically, the Mayor's role was to take account of all political issues and to address them as political issues. He did not see our role as providing the political agenda and solutions. Rather, he drew from an independent position on the knowledge and stimulation provided by the event. Further uncertainties were associated with the location of the event, in a town that can be defined as peripheral to the nearby city. The realisation of the Festival proved that it was possible to conceive and deliver an event that would not normally be associated with the likes of peripheries, namely because of the centripetal forces affecting resource allocation across the institutional, productive and geographical hierarchy of places (Myrdal, 1957). A major element in allowing this could be identified in maintaining the integrity of the activity when the substance of it challenges the existing institutional order. In our specific case, an explicit choice needed to be made when faced with the suggestion of moving the event in the nearby more central town, possibly because hosting such events in peripheral places contrast with established habits of thought. 
As for our self-perception of our own role as academics, we sought to set our agenda from an academic and not a political perspective; to show respect for the political agenda but without compromising our academic judgement; to have the final say on all aspects of the Festival, content and management. Building on the Festival experience, we suggest that careful consideration of the way in which academics relate with policy-makers (and therefore territories) might help to gain further insights on the nature and implications of such interaction. One of the current practices is the use of academia as a pool of knowledge that policy-makers can use (for example, in terms of consultancy) at convenient times to underpin strategic choices. However, we would argue that this sort of interaction, although useful in some contingencies, is restrictive of the broader role of academia on the one hand, but also limitative of the different forms that interaction between academia and localities may assume, on the other.

Reflecting on the experience, we then saw the opportunity of analysing and discussing the nature of academia and the implications of its relationship with different publics, both within and outside a university organisational border. In particular, coming from the Festival experience, we reflected on the meaning of academic freedom, stimulating inter-disciplinary discussion. ${ }^{20}$ One major issue - on which we would not dare to formulate a tentative answer yet - is whether challenging existing practices and routines is, if not promoted, at least accepted when applied to academia itself. Still, this is perhaps not just applied research on creativity and economic development. It is about ourselves as academics, and how much we can push the limits of the paths and trajectories that have been already traced.

\section{ACKNOWLEDGEMENTS}

The authors would like to thank Ermanno Tortia and Romeo Casalini for having discussed various ideas presented in this chapter. Earlier work was presented at the Workshop on Ethnicity, Creativity and Economic Development, Åbo Akademi University, Finland, in December 2008; we are grateful to participants for discussion.

\section{NOTES}

1. Take for example the European Union White Book on Governance (COM, 2001), which identifies a global governance level with which the European Union central governments, regions, cities and the civil society relate. 
2. Hobbes describes the birth of the Leviathan as follows: 'This is more than Consent, or Concord; it is a reall Unitie of them all, in one and the same Person, made by Covenant of every man with every man, in such manner, as if every man should say to every man, I Authorize and give up my Right of Governing my selfe, to this Man, or to this Assembly of men, on this condition, that thou give up thy Right to him, and Authorise all his Actions in like manner. This done, the Multitude so united in one Person, is called a Common-wealth, in latine Civitas. This is the Generation of that great Leviathan, or rather (to speake more reverently) of that Mortall God, to which wee owe under the Immortal God, our peace and defence. . . From this Institution of a Commonwealth are derived all the Rights, and Facultyes of him, or them, on whom the Soveraigne Power is conferred by the consent of the People assembled.' (Hobbes, [1651] 1996, Chapters XVII and XVIII, pp. 117-29).

3. See Hodgson (1993) for a detailed criticism and analysis.

4. According to Hayek (1967) institutions (such as language, law or money) emerge as the outcome of no particular will and not, as contractual (Hobbesian) theories suggest, through the rational design of individuals. From Hayek's evolutionary perspective, institutions are the result of evolution, through a process of adaptation and selection.

5. Routines, as distinct from habits, have been analysed in Hodgson (1993) using the psychological category of procedural memory. Procedural memory, differently from cognition or thought, does not 'have the capability of modelling the external world - that is, of storing representation of objects, events, and relations among them' (Schacter, 1990, p. 301, quoted in Hodgson, 2003, p. 375).

6. From an evolutionary economics perspective, Hodgson (2003) treats individuals' habits and organisational routines as the underlying causal elements (genotype, or gene in biology) that may generate specific behaviours (phenotype, or character in biology). We say 'may' because as Hodgson (ibid., p. 373) stresses by recalling the work of Veblen ([1898] 1998) and Dewey (1922), habits are capabilities, propensities which 'replicate indirectly by means of their behavioural expression'. Behaviours are therefore the manifest effect of (latent) habits. It is behaviour (the phenotype), in social systems, which is imitated and therefore replicated, thus allowing for similar habits to be acquired. Such prospect, which by grounding on the transmission of acquired characters would put emphasis on Lamarckian possibilities, must be however balanced by anthropological and cultural history studies 'that points to the remarkable persistence and replication of (often tacit) social codes and norms of behaviour', thus maintaining 'some fidelity to the 'genotypic' replication of dispositions and rules in social evolution'. (Hodgson, 2003, p. 374).

7. For an analysis of the role of the notion of variety in evolutionary theory, see Hodgson (2003).

8. This principle was originally extended to the entire community, for example to explain the birth of a new collective institution, such as the State in Hobbes. Differently form contractarian approaches, however, deliberation is not a one-off act of delegation.

9. The word is hyphened to put emphasis on the notion of 'liberation' as it happens in the collective context defined by de-liberative processes.

10. 'It is through the camera that I begin to understand the things and the people. That is why I am constantly open to learning and absorbing into the film that which the filming itself reveals, even if that should be in contradiction with what I have written into the script' (Bachmann and Bertolucci, 1973, p. 4).

11. Let us consider again, in this respect, film-making. In Fellini's words, 'Making a film is a metaphor for a type of social utopia: all together doing a thing, directed by one for the good of a cause ... being involved in realizing a dream. It is the same as a group working on a scientific problem and solving it or involved in a geographical research and discovering a new continent, or the more common ideal of inventing and materializing a social form, working out a philosophical problem or creating a work of art. The myth of realization protects by involving you in something bigger than yourself: the aim, the achievement, the goal' (Bachmann and Fellini, 1980, p. 3, emphasis added). 
12. 'We are educated to produce, to judge by the achieved, and this causes our unhappiness. If we stopped working for a goal and started working for the sake of work, we might get closer to some form of psychic health. Our functional education claims there is an achievement out there which needs to be reached, but of course there isn't. All there is, is the trip of going out there' (Bachmann and Fellini, 1980, p. 4).

13. Tendencies here refer to events which happen, for instance, as a result of institutional inertia.

14. 'I think it is important to change one's position and focal length from time to time, see things from other angles. Even if this shocks or creates earthquakes in the mind of those who need security, cover, frameworks and roofs . . . He who gives us, through the example of his life or by the expression of his thought and his fantasy, a new view, helping us to pull our concepts out from under the dusty, dim light and out of that small, rational cage of intellect which imprisoned them and kept them from becoming individually significant for us, robbing us, perhaps, briefly, of the consolation of the familiar, of the daily dreariness, and giving back to them a more mysterious meaning of a less predictable sort-I do not think that such a man should be accused of being pessimistic. He is, instead, a realist' (Bachmann and Fellini, 1980-81, p. 7).

15. Compare deliberative democracy with the model of democracy based on preference aggregation. According to Young (2002, p. 20), in the latter 'citizens never need to leave the private realm of their own interests and preferences to interact with others whose preferences differ.' This aggregative model of democracy is said to carry 'a thin and individualistic form of rationality' (ibid.).

16. Harsanyi (1992) distinguishes between 'actual preferences' and 'informed preferences'. Whilst actual preferences are observed in individuals' choices, behaviour and in their verbal statements, informed or true preferences are harder to see as they are inferred from what individuals' preferences 'would be if they did know some pieces of information they actually do not know' (ibid., p. 29).

17. Harsanyi (1992) distinguishes desires from preferences. Whilst preferences provide information about a person's priorities, desires represent a more fundamental notion regarding humans' inner wishes. People may have different preferences on how to accomplish a specific desire, or different preferences regarding the priority of different desires.

18. Acting here is both speculative and physical.

19. For example, it led to: cooperation of academics with Hi8us, a social enterprise located in the UK and dealing with digital media and disadvantaged groups, on the use of digi-essays in academic activity; a 'Workshop on Ethnicity, Creativity and Economic Development', held in Åbo Akademi University, Finland; the design of an innovative curriculum for the Universitas21 Summer School on 'Diversity through Creativity Innovation and Culture' at the University of Birmingham, UK; the 'Mar Del Plata Winter Festival on Economic Development: Opportunities and Choices', held in Argentina; and a planned second Festival on the specific topic of 'Recapturing Space and Time. Creativity and Economic Development' to be held in Italy.

20. This happened namely through the 'Birmingham Workshops on Academic Freedom', as well as through a specific session hosted at the 2008 Annual Conference of the European Network for Industrial Policy (EUNIP).

\section{REFERENCES}

Adaman, Fikret and Pat Devine (2001), 'Participatory planning as a deliberative democratic process: a response to Hodgson's critique', Economy and Society, 30 (2), 229-39.

Aligheri, Dante (n.d.), 'Inferno', in The Divine Comedy, translated with a 
commentary by Charles S. Singleton, (1970), Princeton, NJ: Princeton University Press, Canto XXVI, p. 279.

Alchian, A.A. (1950), 'Uncertainty, evolution and economic theory', Journal of Political Economy, 58 (June), 211-22.

Arthur, W. Brian (1989), 'Competing technologies, increasing returns, and lock-in by historical events', Economic Journal, 99 (1), 116-31.

Bachmann, Gideon and Bernardo Bertolucci (1973), "Every sexual relationship Is condemned", an interview with Bernardo Bertolucci apropos Last Tango in Paris', Film Quarterly, 26 (3), 2-9.

Bachmann, Gideon and Federico Fellini (1980-81) "“The cinema seen as a woman. ..": an interview on the day City of Women premiered in Rome', Film Quarterly, 34 (2), 2-9.

Berlin, Isaiah (1969), Four Essays on Liberty, Oxford: Oxford University Press.

Borzaga Carlo and Ermanno C. Tortia (forthcoming), 'The growing social content of cooperative firms: an evolutionary interpretation', in L. Becchetti and C. Borzaga (eds), The Economics of Social Responsibility, London: Routledge.

Bruni, Luigino and Robert Sugden (2007), 'The road not taken: how psychology was removed from economics, and how it might be brought back', Economic Journal, 117 (516), 146-73.

Chandler, Alfred (1977), The Visible Hand. The Managerial Revolution in American Business, Cambridge, MA: Harvard University Press.

Chomsky, Noam (1964), Current Issues in Linguistic Theory, 6th edn, 1975, Paris: Mouton.

Chomsky, Noam (1975), 'Prospects for democracy', talk given at MIT, Cambridge, MA, reproduced in C.P. Otero, (ed.) (2003), Chomsky on Democracy and Education, London: Routledge Falmer.

Christensen, Jens (2007), 'Thing or mystery? An approach to critical and creative thinking about economic development, democracy and meaning', paper presented at the Ideas Laboratory of the First International Festival on Creativity and Economic Development, Gambettola, Italy, May.

Coase, R.H. (1937), 'The nature of the firm', Economica, IV, 386-405.

Commission of the European Communities (COM) (2001), 'European governance. A White Paper', COM (2001) 428 Final, Brussels.

Cowling, Keith and Roger Sugden (1998), 'The essence of the modern corporation: markets, strategic decision-making and the theory of the firm', Manchester School, 66 (1), 59-86.

Dewey, John ([1910] 1991), How We Think, Amherst, NY: Prometheus Books.

Dewey, John (1922), Human Nature and Conduct: An Introduction to Social Psychology, New York: Holt.

Dewey, John (1927), The Public and its Problems, Denver, CO: Holt; page numbers refer to the reproduction in: J.A. Boydston (1988), John Dewey. The Later Works Volume 2: 1925-1927, Carbondale, IL and Edwardsville, LU: Southern Illinois University Press.

Dewey, John ([1934] 2005), Art as Experience, New York: Penguin.

Docherty, T. (2008), The English Question or Academic Freedoms, Brighton: Sussex Academic Press.

Dosi, Giovanni (1994), 'Firm, boundaries of the', in G.M. Hodgson, W.J. Samuels and M.R. Tool (eds), The Elgar Companion to Institutional and Evolutionary Economics, Aldershot, UK and Brookfield, USA: Edward Elgar, pp. 229-37.

Douglas, Mary (1987), How Institutions Think, London: Routledge. 
Egidi, Massimo (1987), 'Introduzione', to Salvatore S. Rizzello, L'Economia della Mente, Rome and Bari, Italy: Laterza.

Elster, Jon (ed.) (1986), The Multiple Self, Cambridge: Cambridge University Press and Norwegian University Press.

Harsanyi, John C. (1992), 'Utilities, preferences and substantive goods', WIDER working paper no. 101 (December), United Nations University, Helsinki.

Hayek, Friedrich A. (1945), 'The use of knowledge in society', American Economic Review, 35, 519-30.

Hayek, Friedrich A. (1952), The Sensory Order. An Inquiry into the Foundations of Theoretical Psychology, London and New York: Routledge.

Hayek, Friedrich A. (1967), 'The results of human action but not of human design', in Friedrich A. Hayek, Studies in Philosophy, Politics and Economics, Chicago, IL: University of Chicago Press.

Hayek, Friedrich A. (1982), Law, Legislation and Liberty, London: Routledge.

Hobbes, Thomas ([1651] 1996), Leviathan, edited by Richard Tuck, Cambridge: Cambridge University Press.

Hodgson, Geoffrey M. (1993), Economics and Evolution, Ann Arbor, MI: University of Michigan Press.

Hodgson, Geoffrey (1998), 'Socialism against markets? A critique of two recent proposals', Economy and Society, 27 (4), 450-76.

Hodgson, Geoffrey (2003), 'The mystery of the routine: The Darwinian destiny of an evolutionary theory of economic change', Revue Economique, 54 (2), 355-84.

Hodgson, Geoffrey (2005), 'The limits to participatory planning: a reply to Adaman and Devine', Economy and Society, 34 (1), 141-53.

Jevons, Stanley H. ([1875] 1905), Essays on Economics, London: Macmillan.

Knight, Frank (1921), Risk, Uncertainty and Profit, Boston, MA: Houghton Mifflin Company.

Khurana, R. (2007), From Higher Aims to Hired Hands. The Social Transformation of American Business Schools and the Unfilled Promise of Management as a Profession, Princeton, NJ: Princeton University Press.

Langlois, Richard (2003), 'The vanishing hand: the changing dynamics of industrial capitalism', Industrial and Corporate Change, 12 (2), 351-85.

Montesquieu, Charles De Secondat ([1748] 1989), The Spirit of the Laws, Cambridge: Cambridge University Press.

Myrdal, G. (1957), Economic Theory and Underdeveloped Regions, London: Duckworth.

Penrose, Edith Tilton (1952), 'Biological analogies in the theory of the firm', American Economic Review, 42 (4), 804-19.

Polanyi, Michael (1967), The Tacit Dimension, London: Routledge \& Kegan Paul.

Porter, Michael E. (2003), 'The economic performance of regions', Regional Studies 37 (6-7), 549-78.

Rizzello, Salvatore (1997), L'Economia della Mente, Rome and Bari, Italy: Laterza.

Rostow, W.W. (1959), 'The stages of economic growth', Economic History Review, $12(1), 1-16$.

Sacchetti, Silvia and Roger Sugden (2003), 'The governance of networks and economic power: the nature and impact of subcontracting relationships', Journal of Economic Surveys, 17, 669-91. 
Sacchetti, Silvia and Roger Sugden (forthcoming). 'The organization of production and its publics: mental proximity, markets and hierarchies', Review of Social Economy.

Screpanti, Ernesto (2001), The Fundamental Institutions of Capitalism, London: Routledge.

Simon, Herbert A. (1999), 'The many shapes of knowledge', Revue d'Economie Industrielle, no. 88, (2nd semester), 23-41.

Spencer, Herbert ([1876] 1969), Principles of Sociology, London: Macmillan.

Stabile, Giorgio (2007), Dante e la Filosofia della Natura. Percezioni, Linguaggi e Cosmologie, Florence: Sismel.

Sugden, Robert (1991), 'Rational choice: a survey of contributions from economics and philosophy', Economic Journal, 101, 751-85.

Veblen, Thorstein (1898), 'The instinct of workmanship and the irksomeness of labour', American Journal of Sociology, 4(2), 187-201.

Veblen, Thorstein ([1898] 1998), 'Why is economics not an evolutionary science?', Quarterly Journal of Economics, July, 373-97, reprinted in Cambridge Journal of Economics, 22, 403-14.

Veblen, Thorstein ([1904] 1996), The Theory of the Business Enterprise, New Brunswick, NJ and London: Transaction Publishers.

Williamson, Oliver E. (1985), The Economic Institutions of Capitalism, New York: Free Press.

Young, Iris M. (2002), Inclusion and Democracy, Oxford: Oxford University Press. 